\title{
Indigenous Knowledge in Early Childhood Education: Building a Nest for Reconciliation
}

\author{
Cheryl Kinzel
}

Cheryl Kinzel is the associate dean, Department of Research and Innovation, and director of the Centre for Early Development and Applied Research (CEDAR) at Bow Valley College in Calgary, Alberta. Cheryl holds a bachelor of arts degree from the University of Victoria, a bachelor of education and master of education degree from the University of British Columbia, and a doctoral degree in educational research from the University of Calgary. Cheryl has over 25 years of experience in the field of education covering the areas of teaching, curriculum development, research, program management, and leadership.

Email: ckinzel@bowvalleycollege.ca

This article is based on my dissertation study exploring how Indigenous knowledges were experienced by non-Indigenous students in an ECE diploma program at a Canadian college. Analysis of participants' stories through the lens with Indigenous knowledges and Reconciliation. Critical reflection on these experiences identified key findings: 1) the promise of the truths and realities of Canadian history, and 3) the necessity of experiencing Indigenous knowledges. Through the metaphor of building a nest, I see transformative learning, truth telling, and inclusion of Indigenous knowledges as a path toward Reconciliation of Indigenous and non-Indigenous peoples within early childhood education programs.

Key words: Early childhood education, Indigenous knowledges, Reconciliation, transformative learning, critical pedagogy, initial teacher education, indigenization of critical pedagogy helped identify experiences transformative learning, 2) an acceptance of

The calls to action issued by the Truth and Reconciliation Commission of Canada speak to the moral and ethical obligations that the Canadian government and society must undertake in order to reconcile relations between Indigenous and non-Indigenous peoples. A research study exploring how Indigenous knowledges were experienced by non-Indigenous students in an ECE diploma program at a Canadian college represents a step in the direction of meeting Call to Action \#12 under the heading of Education: "We call upon the federal, provincial, territorial and Aboriginal governments to develop culturally appropriate early childhood education programs for Aboriginal families" (National Centre for Truth and Reconciliation, 2015, p. 2).

From a critical pedagogy perspective, knowledge is not only socially and contextually situated but also powerladen. It is created through interaction with others within the context of any situation (Freire, 2000/1970; Kincheloe, 2008; Kovach, 2009). The culture of colonialism in Canada has worked to negate and exclude Indigenous knowledges from formal and informal learning environments (Battiste, 2013). However, there is potential to work toward changing this, and in this respect I was inspired by Marlene Atleo. As a faculty member (education) at the University of Manitoba and a member of the Ahousaht First Nation, Atleo (2013) argues that non-Indigenous Canadians have an ethical obligation to work to change formal education to support social justice principles that affirm both Indigenous and non-Indigenous learners through cross-cultural praxis. I was further inspired by the influential work of Paulo Freire that explores the role of developing critical consciousness in working toward social justice. Freire critically explored situations of oppression to foster dialogue that leads to praxis or "reflection and action upon the world in order to transform it" (Freire, 2000, p. 51). In a similar way-albeit in a different time and place-I am driven to support postsecondary education that focuses on social justice and Reconciliation.

Embedding Indigenous epistemology and pedagogy within early childhood education (ECE) programming 
at the postsecondary level also aligns with the Accord on Indigenous Education signed by the Association of Canadian Deans of Education (2010), the Universities Canada's Principles on Indigenous Education (2015), the Colleges and Institutes Canada's Indigenous Education Protocol (2014), the Calls to Action issued by the Truth and Reconciliation Commission, and the United Nations' Declaration on the Rights of Indigenous Peoples (2008). As these national and international documents signal, now is the time to work toward Reconciliation between Indigenous and non-Indigenous peoples in Canada by furthering social justice in postsecondary education.

In the study discussed in this article, I draw on the concept of Reconciliation as a catalyst to prompt those within an institution to value the knowledge and experience of Indigenous learners, faculty, and staff of their postsecondary institution by including this knowledge and experience in the day-to-day operations of the college in the study. I also want to ensure that Indigenous knowledges and experiences are reflected in the content of the courses and the programming offered to all learners. My particular focus in this study was to engage with non-Indigenous learners as they explored their own stories of their experience with Indigenous epistemology and pedagogy and to use their experiences as a means to inform the development of curriculum resources for the ECE program on our path to Reconciliation.

\section{Researcher perspective}

Locating myself as a researcher who is simultaneously exploring the possibility and path of her Indigenous heritage and supporting the inclusion of Indigenous ways of being, knowing, and doing in the curriculum of the college was an important aspect of this study. Because of both my lack of connection to an Indigenous community and my lived experiences so far, I find it ethical to locate myself in this research study as a non-Indigenous academic who is exploring my Métis identity and working toward Reconciliation. I find external pressures to choose from a binary of Indigenous or non-Indigenous to be extremely challenging, and I wonder if this perceived need to choose one or the other is a common experience for many Métis people. However, this complex positioning within my story has helped to support strong relationship building with the research participants, the college, and Indigenous communities. Identity, as many scholars have pointed out, can be a crucial component in the success of any Indigenous study (Archibald, 2008; Battiste, 2013; Kovach, 2009; Regan, 2010). It is my moral obligation as one living in and benefiting from historic colonial structures to work toward meeting the calls to action from the Truth and Reconciliation Commission.

\section{Research purpose}

The college where I am employed is a large postsecondary institution in Western Canada. The student population comprises learners from many different cultures; however, the educational framework predominantly favours Western European epistemology and pedagogy. Indigenous learners and learners from non-Western countries share the unfortunate experience of having their own traditional knowledge systems and ways of being, knowing, and doing unrecognized or honoured in North American postsecondary institutions (Archibald, 2008; Asher, 2009; Battiste, 2013; Choules, 2011; Kovach, 2009; Poitras Pratt \& Danyluk, 2017; Smith, 2012). The college sits on the traditional territory of the Blackfoot Confederacy and the ancestral homelands of the Métis Nation. It is located in territory where the Treaty 7 Nations and Indigenous and non-Indigenous graduates of the ECE program work in centres and programs that include Indigenous children and families. In recognizing the original occupants of the lands that the college now occupies and their traditional knowledge systems, my students and I work toward meeting the calls to action of the Truth and Reconciliation Commission. Reconciliation, for me, involves reconceptualizing the scope of early childhood education practices to honour and include Indigenous epistemologies, pedagogies, and child-rearing practices. 


\section{Background}

\section{Hegemonic forms of Western European education}

Epistemological and pedagogical systems frequently represent the values of the dominant community from which they have developed. Here in Canada, as in many other colonial-settler nation states, such systems have developed in ways that privilege one way of knowing and understanding over other ways of knowing and understanding (Battiste, 2013; Kerr, 2014; Kincheloe, 2008; Kovach, 2009; Pacini-Ketchabaw \& Taylor, 2015; Pidgeon, 2008, 2016). This system of hegemony privileges the unquestioned use of Western European epistemological and pedagogical systems as the standard in many Canadian postsecondary institutions (Alexander, 2016; Kovach, 2009; Pacini-Ketchabaw \& Taylor, 2015; Pidgeon, 2008, 2016). As Jeannie Kerr (2014), an Indigenous scholar from the University of Winnipeg, stated, "educational spaces in higher education continue to support and perpetuate structures of colonialism through an epistemic monoculture based in Western scientific materialism” (p. 83). This view positions itself as neutral and maintains that all non-Western European epistemologies and pedagogies are somehow biased or not free of judgment (Kerr, 2014; Kincheloe, 2008).

Positivist scientific epistemology and pedagogy advances the idea that knowledge may be understood to be universal, testable, and generalizable, and is neither subjective nor contextual (Battiste, 2013; Kerr, 2014; Kovach, 2009). This reductionist view does not support an understanding of the multilayered, interconnected, and complex ways that Indigenous cultures view the world (Archibald, 2008; Battiste, 2013; Kincheloe, 2008; Kovach, 2009). Other knowledge traditions, such as interpretivist approaches, seemingly overlap with Indigenous epistemology, viewing knowledge as "oral, particular, local, and timely" (Kerr, 2014, p. 88), dependent upon the context and circumstances at hand.

In light of the ubiquity of Eurocentric epistemology and pedagogy, non-Western European participants studying in the postsecondary system do not typically see their values or belief systems represented in the educational system in which they are immersed. Learners who come to postsecondary education from outside the dominant culture experience the education system differently, depending on how their own values are defined (Battiste, 2013; Kovach, 2009; Pacini-Ketchabaw \& Taylor, 2015). For many Indigenous learners, postsecondary education is a hegemonic system in which their cultures, languages, and traditions are not included, and their knowledge systems are not recognized as legitimate ways of being, knowing, and doing within the institution (Alexander, 2016; Battiste, 2013; Kerr, 2014; Kovach, 2009; Pacini-Ketchabaw \& Taylor, 2015; Pidgeon, 2008, 2016). By continuing to ignore the knowledge traditions of the original occupants of this land, researchers engage in the utilization of a "hegemonic epistemology in league with a dominant power-soaked politics of knowledge operat(ing) to privilege the privileged and further marginalize the marginalized" (Kincheloe, 2008, p. 5). Joe Kincheloe further argues that it is necessary to explore the diverse contexts within which knowledge is situated in order to understand a particular phenomenon: "We must challenge forms of knowledge that are presented to us as value-free" (p. 17). In other words, context and perspective matter.

This understanding of the hegemonic nature of many Western European academic practices in some Canadian postsecondary institutions highlights the problematic nature of non-Indigenous learners' colonization of thought. We have been educated to believe that the epistemological and pedagogical practices we experience in public schooling are neutral, normal, and right (Alexander, 2016; Kincheloe, 2008; Pacini-Ketchabaw \& Taylor, 2015; Regan, 2010). The history of post-contact education in Canada for Indigenous and non-Indigenous peoples has contributed to the negation and erasure of Indigenous ways of being, knowing, and doing, and the ensuing void left by the negation and erasure has been filled with many misunderstandings. 


\section{Research design}

In my study, I employed the qualitative approach of narrative inquiry through storytelling, oriented by critical pedagogy, and supported by Indigenous methodology. I chose this methodology in order to understand nonIndigenous adult learner perspectives on how Indigenous ways of being, knowing, and doing may be experienced in the ECE program at the college. Exploration of the stories I collected has helped to identify non-Indigenous learner understanding of Indigenous epistemology and pedagogy, and it is anticipated that this knowledge may inform the development of curriculum resources for the ECE curriculum to support the Truth and Reconciliation Commission's Call to Action \#12.

The calls to action issued by the Truth and Reconciliation Commission speak to the moral and ethical obligation that Canadian government and society must assume to reconcile Indigenous and non-Indigenous peoples. My research study represents a step toward meeting Call to Action \#12 under the heading of Education: "We call upon the federal, provincial, territorial and Aboriginal governments to develop culturally appropriate early childhood education programs for Aboriginal families" (National Centre for Truth and Reconciliation, 2015, p. 2).

Throughout the entire process of the study, from its initial inception through the completion of my dissertation and defence, I was guided by two Elders from the local community. After receiving ethics approval from my academic institution and the institution at which the study was conducted, one of the Elders held a knowledgesharing session with the five participants in which she shared her Anishnaabe community experiences of child rearing. After this knowledge-sharing session, I collected the learners' stories of child-rearing experiences through conversational interviews as a method of rich qualitative data collection that, as a secondary outcome, moves the participants toward conscientization through praxis (Archibald, 2008; Freire, 2000; Kovach, 2009). I explored this work through the lens of critical pedagogy within an Indigenous storytelling approach that views story as a holistic method of understanding the world (Archibald 2008; Kovach, 2009). Critical pedagogy as a theoretical framework supports reflection and action (praxis) that may lead to transformation of oppressive social or cultural structures. This social justice focus is an integral part of Indigenous methodology and was foundational to the goals of my research study (Kovach, 2009). It is my intent in this article to highlight the praxis experienced by the participants as a positive by-product of beginning to experience Indigenous knowledges. By exploring the non-Indigenous learners' stories of experience with Indigenous ways of being, knowing, and doing, my aim was to support the development of curriculum resources representing potentially transformative resources that work toward social justice.

In an effort to maximize the potential for doing work in a "good way" in my research project and inform the development of curriculum resources toward Reconciliation within our institution, I strove to be transparent about my research goals and to form long-term relationships with the Indigenous community within the college (Archibald, 2008; Bastien, 2004; Battiste, 2013; Kovach, 2009; Little Bear, 2012; Smith, 2012). Ultimately, because of the importance of local place-based knowledge and connection, it is vital that Indigenous knowledge traditions and research involving Indigenous knowledges be validated by local Indigenous communities.

Through conversational interviews, the student participants from the ECE program shared their stories of early learning experiences with Indigenous knowledges and traditions in the ECE program in the college. These students clearly articulated their desire to learn more about Indigenous ways of being, knowing, and doing, and identified it as key to enhancing their skills as future early childhood educators. Their stories of experience were sorted into three major themes identified in the review of the literature: transformative learning, Reconciliation, and Indigenous knowledges. All three themes were identified in the literature review. All the participants focused the majority of their story on the Elder-led knowledge-sharing session in which information about traditional child- 
rearing practices in an Indigenous community was shared.

\section{Analysis}

The findings were derived from conversational interviews exploring non-Indigenous student early learning experiences with Indigenous epistemology and pedagogy. Building from the three identified themes - transformative learning, Reconciliation, and Indigenous knowledges - another process of re-storying these elements through my own lens developed into a collective story, or nest. Like Margaret Kovach (2009), I have used story and thematic analysis to "ensure that the story is available for interpretive analysis by others" (p. 132).

Analysis of the data revealed telling insights from the five participants related to the research question: the participants experienced the beginning of transformative learning, articulated the need for Canada to work toward Reconciliation as a nation but did not demonstrate an understanding of this work as individuals, rather viewing it as the work of the government, and desired more exposure to Indigenous knowledges and a deeper understanding of these knowledges. Indigenization as systemic and structural change was missing from the qualitative data, indicating a lack of understanding of or exposure to the depth of this concept. The participants instead articulated a piecemeal approach that suggested embedding cultural ceremonies and practices into the regular (dominant) curriculum framework.

The early learning experiences of the college students, who were in the second and third terms of their programexplored through participation in the Indigenous history, identity, and culture course, as well as the Elder-led knowledge-sharing session-represent the only experiences with Indigenous knowledges in the ECE program identified by the participants. This knowledge, along with the assumptions about Indigenous peoples and knowledge demonstrated in the interviews, indicates that there is a need to bring more material into our curriculum to build a substantial nest of learning grounded in social justice that could help realize the goals of Reconciliation.

The stories shared by the participants represent the foundational elements of the educational nest: the sticks and twigs of transformative learning through critical pedagogy, the mud and string of truth telling and relationships that bind, and the feathers of spirit, heart, mind, and body that line the nest (Archibald, 2008). All these materials are needed to form the nest as we move toward answering the calls to action of the Truth and Reconciliation Commission. This nest cradles and supports the important and challenging work of Reconciliation.

\section{The collective story of experience: An eye-opening start}

This story represents my interpretation of the participants' collective story of experience and should be viewed through that subjectivelens. I have used pseudonyms throughout. The participants started a journey of transformative learning, part of the process of critical consciousness (Freire, 1970, 1973, 1985; Mezirow, 2003), when they began learning about Indigenous history in the post-contact era through their participation in an Indigenous history, identity, and culture course, the Elder-led knowledge-sharing session, and reflection through the conversational interviews. Willow shared her initial thoughts about the Indigenous history, identity, and culture course:

When I saw this was actually a class that was part of my program I was thinking it was kind of weird; I didn't see how it was relevant. But then I was in the class and it was eye opening. (Personal communication, January 22, 2018)

Through engaging in authentic dialogue with the Elder during the knowledge-sharing session, the Indigenous history, identity, and culture instructor during the term, and me during the conversational interviews, the participants reflected on their own lived experiences, values, and beliefs. This stimulated a recognition of unjust 
power structures and a desire to move toward social justice (Freire, 1970, 1973, 1985). As Lexa reflected on the legacy of Indian residential schools, she shared that "I want to better understand that [trauma] so that I can integrate my own beliefs and feelings to try to help improve the barrier between Whites and Aboriginal peoples" (personal communication, January 19, 2018). This process, through reflection and the act of participating in all facets of the research project, brought the participants to a point where they could recognize the inequitable power structures between Indigenous and settler/immigrant/refugee populations encountered in their lived experiences.

The process of beginning transformative learning through praxis and conscientization moved the participants to want to explore the concept of Reconciliation. Although they did not use the term Reconciliation, they articulated concepts that referenced the importance of truth telling, healing, and partnerships between Indigenous and nonIndigenous people and communities rooted in respectful relationships and dialogue. The participants recognized their potential influence when working with children, family, and community in their roles as early childhood educators. Theresa articulated this when she stated, "Why is it important; what is early child care? A child and a family, a child and the parents. The best way to introduce a culture is from the beginning" (personal communication, January 24, 2019). All the participants articulated a desire to see a change in the relationships between Indigenous and non-Indigenous peoples in Canada, and they saw this possibility being advanced through their professional roles. Early childhood educators have the opportunity to begin positive relational practice founded on respect as we move toward Reconciliation and the path to social justice. It is vital that instructors in early childhood education teacher preparation programs understand the power of critical pedagogy to change the systems of oppression in Canada.

The recognition of the lived realities of Indigenous peoples and the realization that they wanted to work toward Reconciliation spurred the participants to reflect on the importance of Indigenous knowledges in the lives of Indigenous and non-Indigenous children and families and in their own practice as early childhood educators. After participating in the Elder-led knowledge-sharing session in which they heard stories of traditional childrearing practices, Tammy referenced "all the hard work that went into daily life ... and the love that was in the family" (personal communication, January 22, 2018). This reflection and understanding is necessary to support connections and relationships. The participants expressed a desire to have a deeper understanding of and exposure to Indigenous cultures, ceremonies, languages, values, and beliefs: "By learning and understanding more of the Indigenous people and their values/beliefs, the more I can try and provide that at any centre I work at" (Mariella, personal communication, February 4, 2018). While this is not an indication of critical consciousness or praxis, it does indicate that the foundations of an authentic dialogue have started. These foundations are necessary in order to move purposefully down the path of humanization toward social justice (Friere, 1973, 1985).

Through a set of loosely framed prompts, the student participants were invited to talk about their experiences and perceptions with Indigenous knowledges in their ECE courses. Throughout these conversations they did not articulate or explore their own roles or the roles of other settler/immigrant/refugee students in doing the difficult work that moves toward Reconciliation (Poitras Pratt \& Danyluk, 2017; Regan, 2010). Theresa articulated the idea of federal responsibility when she stated that "the silence from the government has made it (the history of Canada with respect to Indigenous peoples) more difficult to understand” (personal communication, January 24, 2018). This is not altogether surprising given the initial experiences the participants had as part of their ECE curriculum. This research project represents only the beginning of their learning, and they have not been encouraged to explore their own positionality and responsibility in the difficult work of Reconciliation. It is obvious from the views expressed by the participants that more work is needed to develop individual and systemic change that will work toward Reconciliation and the inclusion of Indigenous pedagogy and epistemology in the ECE program at the college. It is also important to note that it is not possible for a single curriculum or framework to be inclusive 
of all Indigenous cultures (Bjartviet \& Author, 2018; Poitras Pratt \& Danyluk, 2017; Regan, 2010). Rather, the goal is to work toward a system and framework that moves away from Western European epistemology and pedagogy to that of a regionally developed model co-constructed with Indigenous communities as the foundation for all teaching and learning in the college ECE program (Battiste, 2013; Bastien, 2004; Curwen Doige, 2003; Kovach, 2009; Smith, 2012; Taylor, 2017; Tremblay, Gokiert, Georgis, Edwards, \& Skrypnek; 2013).

From this collective story where a nest has been built using essential thematic materials, the next step is to fill the nest with possibility. In a metaphorical sense, possibility is contained within insights (or findings) that are quite fragile but filled with great potential that needs the ongoing attention of those who care. The following section sets out the recommendations for the building of a learning nest.

\section{Discussion and recommendations}

The specific purpose of this small-scale qualitative study was to gain an understanding of the stories of experience of non-Indigenous ECE students in relation to the extent of their familiarity with Indigenous knowledges. Exploration of these stories helped to identify non-Indigenous learners' early understandings of Indigenous epistemology and pedagogy and highlighted three themes that were found in all conversational interviews. From the themes of Indigenous knowledges (Spirit, Heart, Mind, Body), Reconciliation, and transformative learning, I constructed a single re-storied account of what students reported. Of note is that exploration of the participant conversations indicated that this early learning experience held potential for students to understand the importance of including Indigenous perspectives in their future professional roles. However, the program's developers will have to carefully consider and design a curriculum that can help students identify and explore their own positionality in this learning. This will require the integration of Indigenous and critical perspectives that focus on the social justice aspect of this work.

Throughout the collective story of experience, a lack of deep understanding of Indigenous knowledges became obvious, and no participants mentioned the complexities of Indigenization. However, there is some evidence to suggest the presence of initial threads of transformative learning that could lead to reconciliation.

\section{The promise of transformative learning}

Through my exploration of transformative learning theory, I found certain aspects of this theory closely aligned with critical pedagogy: a shared emphasis on critical reflection of assumptions and beliefs is crucial for challenging perspectives and, in the case of critical pedagogy, for challenging oppression (Cranton, 2011, 2013; Groen \& Kawalilak, 2014a; Jarvis, 2010; Kitchenham, 2008; Mackinley \& Barney, 2014). While transformative learning may have social justice goals, critical pedagogy has social justice as a foundation (Glass \& Newman, 2015; McLaren, 1999; Smith, 2012). The engagement of both the participants and the local postsecondary institutions with initial transformative learning experiences demonstrates the potential for creating a path of critical consciousness. It is necessary to engage in a focused and targeted adoption of Indigenous knowledges and critical pedagogy not only in the ECE classroom but also in the postsecondary institution in general in order to move toward better relations between Indigenous and non-Indigenous peoples. The foundation of transformative learning and critical pedagogy will form the framework for the nest needed to support the work of Reconciliation.

\section{The truths and realities of Canadian history}

The move toward Reconciliation emphasizes the importance of truth telling, healing, and partnerships between Indigenous and non-Indigenous people and communities rooted in respectful relationships and dialogue. The 
local institutional engagement with truth telling for some programs may represent a conscious and targeted effort to move toward Reconciliation as articulated by the Truth and Reconciliation Commission. These actions demonstrate the possibility of the inclusion of critical pedagogy. The "eye-opening" truth experienced by the students as a result of listening to the Elder and taking the Indigenous knowledge course has the potential to start them on a journey of transformative learning. By making such truth-telling courses mandatory for specific programs, I see efforts to begin the dialogue necessary to develop both critical consciousness and the idea of humanization (Freire, 1973, 1985). Additionally, I see a pedagogy of hope in these actions (Freire, 1992). If the college leadership did not truly believe that these actions would lead to a better, more just, and more hopeful postsecondary environment, they would not expend the time and resources on them. Purposeful engagement with critical pedagogy and the pedagogy of hope are necessary in our postsecondary environments. The truth telling and emphasis on respectful relationships and dialogue found in Reconciliation are the string and mud, the dirty and tangly bits that hold together our nest of critical pedagogy and hope.

\section{Including Indigenous knowledges}

Indigenous knowledges or Indigenous ways of being, knowing, and doing are about relationships and connections throughout our physical, mental, and spiritual selves (Bastien, 2004; Battiste, 2013). I have placed Indigenous knowledges in the larger scope of Indigenization because engagement with Indigenous ways of being, knowing, and doing can be found in discussions of Indigenization. Indigenization of postsecondary education has been defined to include Indigenous governance structures; the revitalization of Indigenous languages; respectful, collaborative research; and the inclusion of Indigenous epistemology and pedagogy to support all learners (Academica Forum, 2016; ACDE, 2010; Barnard, 2015; Czyzewski, 2011; Colleges and Institutes Canada, 2014; Federation for the Humanities and Social Sciences, 2017; Louie, Poitras Pratt, Hanson, \& Ottmann, 2017; MacDonald, 2016; Ottmann, 2013; Poitras Pratt \& Danyluk, 2017; Universities Canada, 2015).

\section{Indigenization requires structural and systemic change}

The theme of Indigenization of the overall structure, operation, and curriculum of the college or ECE program was not mentioned by the participants. This is not completely surprising given that at the time of the study the concept of Indigenization had been introduced only minimally to members of our campus community. The participants referenced a desire to have Indigenous cultural understanding and Indigenous ceremony included in the ECE program both as a means to support Indigenous and non-Indigenous children and because of their own interest in the subject. The participants did not connect this to a more systemic approach to changing the epistemology and pedagogy of the ECE program or the overall structure of the college to make space for Indigenous knowledges. This early learning stage of Indigenization does not consider the systemic and societal oppression inherent in dominant pedagogy and epistemology, and neither does it explore the concept of decolonization, which comes before Indigenization (Ashton, 2015; Battiste, 2013; Bjartviet \& Author, 2018; Kerr, 2014; Kincheloe, 2008; Kovach, 2009; Pidgeon, 2008, 2016). None of the participants referenced the idea of Indigenization as reframing the structure and operation of the ECE program in their conversational interviews. They referred solely to changing the curriculum by infusing Indigenous content. This notable gap in understanding the concept of Indigenization needs to be addressed holistically by the college through the exploration of structural and systemic change, in addition to including Indigenous ways of being, knowing, and doing in the ECE curriculum, to work toward meeting Call to Action \#12. Indigenous knowledges or Indigenous ways of being, knowing, and doing are the final component in the building of our educational nest. We need the solid framework of sticks and twigs (critical pedagogy), the sticky, messy bits of mud and string (truth telling and relationship), and the beautiful and unique feathers (Indigenous knowledges) as we work toward Reconciliation. This nest will be challenging to build but it 
will be worth the effort because it embodies hope for our future.

\section{Critical consciousness and dialogue}

The efforts of the local postsecondary institutions and the findings from this research study with respect to Reconciliation, Indigenization, and transformative learning represent a conscious and targeted effort to move toward Reconciliation as articulated by the Truth and Reconciliation Commission, and demonstrate the potential for the inclusion of critical pedagogy as a method of instruction to work toward social justice (Freire, 1970, 1973, 1985). In keeping with the Truth and Reconciliation Commission recommendations, I maintain that our role as postsecondary instructors is to respectfully consider and include Indigenous perspectives and viewpoints because of the historical relationship that Indigenous peoples have to the land on which the college is located. Understanding and acknowledging the history, culture, beliefs, and lived reality of Indigenous peoples is a requirement in order for transformative education to take place in this postsecondary context.

On the path toward Reconciliation, the college has a responsibility to continue to work in the realm of critical pedagogy and expand its efforts to engage the college community in truth telling and exploration that will result in authentic and critical dialogue (Freire, 1970, 1973, 1985). I believe that the college is working to follow this path and that we need to ensure that all the stakeholders are engaged in authentic dialogue that challenges our social, cultural, and political beliefs, values, and lived realities. This means that I will be engaging with Indigenous Elders, community members, and organizations to help support the realization of the recommendations outlined below. We cannot move toward Reconciliation without the input and guidance of Indigenous communities, otherwise we risk not only continuing but also reinforcing colonization. We must embark on this path together. Engaging all the stakeholders in the practice of critical pedagogy supports the nest of hope into which Indigenous knowledges can be meaningfully embedded in the college curriculum.

The college leadership has offered full support with this project, which I see as evidence of their support for critical pedagogy as a means through which to work toward institutional critical consciousness and praxis. Above all, I see hope. This hope brings me to the following reflections.

\section{Reflections}

Through discussions with an Elder, the director of the Indigenous Centre, and other community members, I have learned a great deal about the importance of relational practice, community, and taking the time to ensure that I am developing good relationships and working alongside of and in support of community. I have also learned a great deal about the importance of following the guidance of Elders and knowledge keepers in my work. I will ensure that my own future research includes and privileges the voices of those in my community who guide me in this work. It is vital that research that includes Indigenous Peoples or Indigenous knowledges be done in collaboration with the Indigenous community.

The entire trajectory of this research project and the experience of travelling in relationship with the participants, the Anishinaabe Elder, and Métis knowledge keeper as well as the director of the college's Indigenous Centre on this journey has changed who I am and how I see the world. I would like to emphasize the importance of the authentic relationships I developed with the Elder, the knowledge keeper, and the director of the Indigenous Centre, who have helped support me and guide me on this research path. Through the work of this project, I am on a journey to discover who I am based on my own story and experiences, and I am also learning how to support the work of Reconciliation that is my responsibility. I am learning to work in relationship with community, and, just as importantly, I am learning to be Métis. 


\section{Recommendations}

As we move forward to build an educational nest, we need to keep in mind the important themes identified through this study. Purposeful engagement in transformative learning or critical pedagogy is necessary as the foundation of this nest. Truth telling and respectful relationships between Indigenous and non-Indigenous peoples form the mud and string that holds this nest together. The inclusion of Indigenous knowledges or Indigenous ways of being, knowing, and doing at the college will fill the nest with feathers to support us on our journey to Reconciliation. These themes provide direction for recommendations as we move toward Reconciliation and offer guidance in the development of curriculum resources for early childhood education programs and wider college communities.

\section{Realizing the full potential of the early childhood education program}

- In order to support engagement with Indigenous communities and the inclusion of lived experience with Indigenous knowledges in college programming, institutions will need to hire more Indigenous faculty and staff who represent local community members.

- To combat the history of colonial education and foster truth telling and dialogue, postsecondary institutions should create a course on Reconciliation that uses critical pedagogy and its concepts as a foundational teaching approach.

- To support the calls to action of the Truth and Reconciliation Commission, institutions should make a course on Reconciliation mandatory for all faculty and staff.

- To ensure a collective approach of being in a relationship with the community and bringing together the threads of language, culture, values, relationship, connection, community, land/place, and spirit, postsecondary institutions should engage with community and knowledge keepers in all stages of curriculum work.

- To ensure that the work of Reconciliation continues, embed these recommendations in institutional structures through policies and programming so that the work of Reconciliation continues in the face of a change in college, provincial, or federal leadership.

These recommendations will support students in ECE teacher training programs and in their future work as early childhood educators with Indigenous and non-Indigenous children and families. They hold promise for supporting our postsecondary communities in a broader sense. If done in a "good way" (Kovach, 2009), guided by and in collaboration with the Indigenous community, these recommendations will also work toward meeting the Truth and Reconciliation Commission's Call to Action \#12 regarding the development of culturally appropriate early childhood education programs for Indigenous families. These recommendations can be embedded within the educational nest that supports those on the path of Reconciliation.

\section{Summary}

I have explored the themes identified by analyzing the participant interviews through the lens of critical pedagogy. This exploration has indicated that although we have begun to explore the path toward Reconciliation, we have a long way to go and a lot of work to do. I have shared recommendations that will support the college and the ECE program as we work to meet the calls to action of the Truth and Reconciliation Commission. I propose that these recommendations have a broader application and, if taken up by Canadian postsecondary institutions, can support us on our journey of Reconciliation. This work will not be easy and it will take an exploration of our own power and positionality as we move forward. 
The background of colonialism in Canada has worked to negate Indigenous knowledges. Working toward building an educational nest that has critical pedagogy as the framework of sticks and twigs, engagement with truth telling and authentic relationships as the mud and strings that bind it together, and feathering this nest with Indigenous knowledges is necessary to provide a foundation to support Reconciliation between Indigenous and non-Indigenous peoples. I am committed to working toward Reconciliation in my both my personal and professional practice. I call on those reading this work to join me. 


\section{References}

Academica Forum. (2016, September 19). How indigenization can support students while honouring Reconciliation. Retrieved from https://forum.academica.ca/forum/how-indigenization-can-support-students-while-honouring-reconciliation

Alexander, K. (2016). Childhood and colonialism in Canadian history. History Compass, 14(9), 397-406. Retrieved from https:// onlinelibrary-wiley-com.ezproxy.lib.ucalgary.ca/doi/epdf/10.1111/hic3.12331

Archibald, J. (2008). Indigenous storywork: Educating the heart, mind, body, and spirit. UBC Press: Vancouver.

Asher, N. (2009). Writing home/decolonizing text(s). Discourse: Studies in the Cultural Politics of Education, 30(1), 1-13. https://doi. org/10.1080/01596300802643033

Ashton, E. (2015). Troubling settlerness in early childhood curriculum development. In V. Pacini-Ketchabaw \& A. Taylor (Eds.), Unsettling the colonial places and spaces of early childhood education (pp. 81-97). New York, NY: Routledge.

Association of Canadian Deans of Education (ACDE). (2010). Accord on Indigenous education. Retrieved from https://csse-scee.ca/ acde/2017/08/19/events-2-2/

Atleo, M. (2013). The zone of Canadian Aboriginal adult education. In T. Nesbit, S. Brigham, N. Taber, \& T. Gibb (Eds.), Building on critical traditions: Adult education and learning in Canada (pp. 39-50). Toronto, Canada: Thompson Nelson.

Barnard, D. T. (2015, June 7). The role of Canada's universities in reconciliation. Ottawa Citizen. Retrieved from http://ottawacitizen.com/ news/national/david-t-barnard-the-role-of-canadas-universities-in-Reconciliation

Bastien, B. (2004). Blackfoot ways of knowing: The worldview of the Siksikaitsitapi. Calgary, Canada: University of Calgary Press.

Battiste, M. (2013). Decolonizing education: Nourishing the learning spirit. Saskatoon, Canada: Purich Publishing Ltd.

Bjartveit, C., \& Kinzel, C. (2019). Navigating power and subjectivity: Cultural diversity and transcultural curriculum in early childhood education. Journal of Childhood Studies, 44(1), 80-91. https://doi.org/10.18357/jcs.v44i1.18779

Choules, K. (2011). Social change education context matters. In S. Merriam \& P. Grace (Eds.), Contemporary issues in adult education (pp. 149-169). San Francisco, CA: Jossey-Bass.

Colleges and Institutes Canada (CICAN) (2014). Indigenous education protocol. Retrieved from http://www.collegesinstitutes.ca/protocol

Cranton, P. (2011). A theory in progress. In S. Merriam \& A. Grace (Eds.), Contemporary issues in adult education (pp. 321-339). San Francisco, CA: Jossey-Bass.

Cranton, P. (2013). Transformative learning. In P. Mayo (Ed.) Learning with adults: A reader (pp. 267-274). The Netherlands: Sense Publishers.

Curwen Doige, L. A. (2003). A missing link: Between traditional Aboriginal education and the western system of education. Canadian Journal of Native Education, 27(2), 144-160. Retrieved from https://search-proquest-com.ezproxy.lib.ucalgary.ca/ docview/230304290/fulltextPDF/11C54A041E464FD6PQ/1?accountid=9838

Czyzewski K. (2011). The Truth and Reconciliation Commission of Canada: Insights into the goal of transformative education. The International Indigenous Policy Journal, 2(3), 1-12. Retrieved from https://ir.lib.uwo.ca/cgi/viewcontent. cgi? referer $=\&$ httpsredir $=1 \&$ article $=1026 \&$ context $=$ iipj

Federation for the Humanities and Social Sciences (2017). Reconciliation and the academy. Retrieved from https://www.ideas-idees.ca/ reconciliation-and-academy

Freire, P. (1973). Education for critical consciousness. New York, NY: Seabury Press.

Freire, P. (1985). The politics of education: Culture, power and liberation. South Hadley, MASS: Bergin \& Garvey Publishers, Inc.

Freire, P. (1992). Pedagogy of hope: Reliving pedagogy of the oppressed. New York, NY: Bloomsbury. 
Freire, P. (2000). Pedagogy of the oppressed. New York, NY: Bloomsbury. Originally published 1970.

Glass, R. D. \& Newman, A. (2015). Ethical and epistemic dilemmas in knowledge production: Addressing their intersection in collaborative, community-based research. Theory and Research in Education, 13(1) 23-37. https://doi.org/10.1177/1477878515571178

Groen, J., \& Kawalilak, C. (2014). Pathways of adult learning: Professional and educational narratives. Toronto, Canada: Canadian Scholars' Press.

Jarvis, P. (2010). Adult education and lifelong learning: Theory and practice, $4^{\text {th }}$ Ed. New York, NY: Routledge.

Kerr, J. (2014). Western epistemic dominance and colonial structures: Considerations for thought and practice in programs of teacher education. Decolonization: Indigeneity, Education \& Society, 3(2), 83-104. Retrieved from https://pdfs.semanticscholar.org/ d445/320e5b2c61c3786641d6ad367a2cf945a06b.pdf

Kincheloe, J. L. (2008). Critical pedagogy and the knowledge wars of the twenty-first century. International Journal of Critical Pedagogy, 1(1), 1-22. Retrieved from http://freireproject.org/wp-content/journals/TIJCP/Vol1No1/48-38-1-PB.pdf

Kitchenham, A. (2008). The evolution of John Mezirow's transformative learning theory. Journal of Transformative Education, 6(2), 104123. Retrieved from http://journals.sagepub.com.ezproxy.lib.ucalgary.ca/doi/pdf/10.1177/1541344608322678

Kovach, M. (2009). Indigenous methodologies. Toronto, Canada: University of Toronto Press.

Little Bear, L. (2012). Traditional knowledge and humanities: A perspective by a Blackfoot. Journal of Chinese Philosophy, 39(4), 518-527. Retrieved from https://onlinelibrary-wiley-com.ezproxy.lib.ucalgary.ca/doi/epdf/10.1111/j.1540-6253.2012.01742.x

Louie, D., Poitras Pratt, Y., Hanson, A., \& Ottmann, J. (2017). Applying Indigenizing principles of decolonizing methodologies in university classrooms. Canadian Journal of Higher Education, 47(3), 16-33. Retrieved from http://journals.sfu.ca/cjhe/index. $\mathrm{php/cjhe/article/view/187948}$

MacDonald, M. (2016, April 6). Indigenizing the academy. University Affairs. Retrieved from http://www.universityaffairs.ca/features/ feature-article/indigenizing-the-academy/

Mackinley, E., \& Barney, K., (2014). Unknown and unknowing possibilities: Transformative learning, social justice, and decolonizing pedagogy in Indigenous Australian studies. Journal of Transformative Education, 12(1), 54-73. Retrieved from http://journals. sagepub.com.ezproxy.lib.ucalgary.ca/doi/pdf/10.1177/1541344614541170

McLaren, P. (1999). A pedagogy of possibility: Reflecting upon Paulo Freire's politics of education. Educational Researcher, 28(2), 49-56. https://doi.org/10.3102/0013189X028002049

Mezirow J. (2003). Transformative learning as discourse. Journal of Transformative Education, 1(1), 58-63. Retrieved from http://journals. sagepub.com.ezproxy.lib.ucalgary.ca/doi/pdf/10.1177/1541344603252172

National Centre for Truth and Reconciliation (2015). Truth and Reconciliation Commission of Canada: Calls to action. Retrieved from http://nctr.ca/assets/reports/Calls_to_Action_English2.pdf

Ottmann, J. (2013). Indigenizing the academy: Confronting "contentious ground." Indigenizing the Academy: Special edition of The Morning Watch, 8-24. Retrieved from http://www.mun.ca/educ/faculty/mwatch/vol40/winter2013/indigenizingAcademy.pdf

Pacini-Ketchabaw, V., \& Taylor, A. (2015). Unsettling the colonial places and spaces of early childhood education in settler colonial societies. In A. Taylor \& V. Pacini-Ketchabaw (Eds.), Unsettling the colonial places and spaces of early childhood education (pp. 1-17). New York, NY: Routledge

Pidgeon, M. (2008). Pushing against the margins: Indigenous theorizing of "success" and retention in higher education. Journal of College Student Retention, 10(3), 339-360. https://doi.org/10.2190/CS.10.3.e

Pidgeon, M. (2016). More than a checklist: Meaningful Indigenous inclusion in higher education. Social Inclusion, 4(1), 77-91. http:// dx.doi.org/10.17645/si.v4i1.436

Poitras Pratt, Y. \& Danyluk, P. (2017). Learning what schooling left out: Making an Indigenous case for critical service-learning and 
reconciliatory pedagogy within teacher education. Canadian Journal of Education, 40(1), 1-29. Retrieved from https://searchproquest-com.ezproxy.lib.ucalgary.ca/docview/1880381512/fulltextPDF/B10B9B69E22E416APQ/1?accountid=9838

Poitras Pratt, Y., Louie, D., Hanson, A., \& Ottmann, J. (2018). Indigenous education and decolonization. Oxford Research Encyclopedia of Education, January 2018, 1-32. https://dx.doi.org/10.1093/acrefore/9780190264093.013.240

Regan, P. (2010). Unsettling the settler within: Indian residential schools, truth telling, and reconciliation in Canada. Vancouver, Canada: UBC Press.

Smith, L., (2012). Decolonizing methodologies: Research and Indigenous peoples. New York, NY: Zed Books.

Taylor, B. (2017). Toward reconciliation: What do the calls to action mean for early childhood education? Journal of Childhood Studies, 42(1), 48-53. https://doi.org/10.18357/jcs.v42i1.16887

Tremblay, M., Gokiert, R., Georgis, R., Edwards, K., \& Skrypnek, B. (2013). Aboriginal perspectives on social-emotional competence in early childhood. The International Indigenous Policy Journal, 4(4), 2. Retrieved from https://ir.lib.uwo.ca/cgi/viewcontent. cgi? referer $=\&$ httpsredir $=1 \&$ article $=1151 \&$ context $=$ iipj

United Nations. (2008). Declaration on the rights of Indigenous peoples. Retrieved from http://www.un.org/esa/socdev/unpfii/ documents/DRIPS_en.pdf

Universities Canada. (2015). Universities Canada principles on Indigenous education. Retrieved from http://www.univcan.ca/mediaroom/media-releases/universities-canada-principles-on-indigenous-education/ 